April 2010

\title{
Genocidal Intentions: Social Death and the Ex-Gay Movement
}

Sue E. Spivey

Christine M. Robinson

Follow this and additional works at: https://digitalcommons.usf.edu/gsp

\section{Recommended Citation}

Spivey, Sue E. and Robinson, Christine M. (2010) "Genocidal Intentions: Social Death and the Ex-Gay Movement," Genocide Studies and Prevention: An International Journal: Vol. 5: Iss. 1: Article 5.

Available at: https://digitalcommons.usf.edu/gsp/vol5/iss1/5

This Articles is brought to you for free and open access by the Open Access Journals at Digital Commons @ University of South Florida. It has been accepted for inclusion in Genocide Studies and Prevention: An International Journal by an authorized editor of Digital Commons @ University of South Florida. For more information, please contact digitalcommons@usf.edu. 


\title{
Genocidal Intentions: Social Death and the Ex-Gay Movement
}

\author{
Sue E. Spivey and Christine M. Robinson \\ James Madison University
}

In this article, the authors contribute to the literature on predicting and preventing genocide in an international context, focusing on social death practices elaborated in articles II(b)-(e) of the 1948 United Nations Convention on the Prevention and Punishment of the Crime of Genocide (UNCG). Analyzing ex-gay movement texts, the authors apply James Waller's theoretical framework, which explains how ordinary people commit extraordinary acts of brutality, to the rhetoric and public policy advocacy of prominent ex-gay movement organizations and entrepreneurs. Further, they examine the extent to which this new religious movement promotes public policies in the United States and globally, and argue that these policies constitute social death as genocide of gay, lesbian, bisexual, and transgender peoples based on the UNCG definition. The authors conclude that emphasizing mass murder at the expense of social death constricts our view of genocide at an enormous human cost, including predicting and preventing mass murder, and accentuating the aftermath of genocide, leaving articles II(b)-(e) diminished, understudied, and, therefore, discounted in comparison. They suggest that revitalizing scholarship on social death will broadly enrich the field of genocide studies and enhance collective efforts to forecast and avert genocide in all of its manifestations.

Key words: genocide, religion, homosexuality, politics, social movements

\section{Genocidal Intentions: The Ex-Gay Movement and Social Death}

Rapidly proliferating since the $1990 \mathrm{~s}$, the cross-disciplinary study of genocide has been conceptualized and approached in vastly different ways. Since 1948, international law has defined the characteristics and forms of genocide. However, genocide scholars have identified a number of conceptual shortcomings in the United Nations' criteria. Four of the most prominent are that: (1) the definition of genocide lacks clarity, (2) the definition fails to include political and social groups, (3) the meaning of "intent" (as in "intent to destroy") is unclear, and (4) the scope of destruction ("in whole or in part") is not clearly defined. ${ }^{1}$ Given these concerns, scholars have invested considerable attention toward proposing alternative conceptualizations of genocide. In the end, however, international law recognizes only the official definition from the United Nations Convention on Prevention and Punishment of the Crime of Genocide (UNCG).

Article II of the UNCG defines genocide as "any of the following acts committed with intent to destroy, in whole or in part, a national, ethnical, racial or religious group, as such: (a) Killing members of the group; (b) Causing serious bodily or mental harm to members of the group; (c) Deliberately inflicting on the group conditions of life calculated to bring about its physical destruction in whole or in part; (d) Imposing measures intended to prevent births within the group; and/or (e) Forcibly transferring children of the group to another group."2

Sue E. Spivey and Christine M. Robinson, "Genocidal Intentions: Social Death and the Ex-Gay Movement." Genocide Studies and Prevention 5, 1 (April 2010): 68-88. (C) 2010 Genocide Studies and Prevention. doi:10.3138/gsp.5.1.68 
In addition to these conceptual issues, scholars from different disciplines largely focus on separate sections of the UNCG. Researchers in political science, international relations, international law, history, and (some in) sociology typically conceptualize and examine genocide as mass murder, distinguishing it categorically from other human atrocities that constitute genocide. ${ }^{3}$ These researchers argue that mass murder, Article II(a), is a tangible, measurable entity compared to the forms of genocide listed in articles II(b) through II(e), the muddled social and cultural dimensions. Here scholars contend that limiting the definition to mass murder enhances its moral status. Further, they argue that expanding the definition reduces the moral opprobrium attached to the atrocity. While this emphasis has proven fruitful, it has also constricted our view, accentuating the aftermath of mass murder while neglecting other forms of genocide. Debates among these scholars have been limited to legal matters after the fact; including the role of diplomacy, sovereignty, failed states, intervention strategies, and punishment procedures. This emphasis on genocide as mass murder, postmortem, has left UNCG articles II(b) through II(e) diminished, understudied, and, as a result, discounted.

In contrast, anthropologists, social philosophers, social psychologists, and (prior to the early 1990s) sociologists predominantly emphasize the social and cultural processes which precede and accompany physical death, including those forms of genocide elaborated in UNCG articles II(b)-(e). ${ }^{4}$ These scholars conceptualize genocide as part of a continuum of oppression, violence, and inequality, locating mass murder at one end and social death and symbolic violence at the other. Building from Orlando Patterson's ${ }^{5}$ concept of social death, philosopher Claudia Card asserts that genocide is not, in its essence, physical death, since genocide involves physical and psychological torture, humiliation, and other forms of degradation. ${ }^{6}$ Rather, she argues, genocide is fundamentally about the destruction of a culture-the annihilation of cultural identity, heritage and intergenerational bonds, associations, and relations: "The very idea of selecting victims by social group identity suggests that it is not just the physical life of victims that is targeted but the social vitality behind that identity." 7 This is why the UNCG definition of genocide includes physical and psychological torture, the seizing of a group's children, or denying a group's capacity to reproduce. Thus, these scholars focus on these means of eradicating the cultural identity of a group for the next generation, or social death, as a primary issue in genocide research. Yet in comparison, the literature on mass murder is considerably more substantial. Regardless of the emphasis, scholars agree that genocide is a planned, coordinated, long-term process, not simply a spontaneous event. Further, scholars agree that the purpose of studying genocide is prediction and prevention. ${ }^{8}$ In this article, we seek to contribute to this objective by identifying the ideology and practices that constitute social death forms of genocide against lesbian, gay, bisexual, and transgender (LGBT) peoples, perpetrated by the ex-gay movement.

Prior to the development of genocide as a type of crime under international law, male and female homosexuals in European Christian nations were routinely put to death or tortured for the crime of sodomy from the fourteenth through the twentieth century. ${ }^{9}$ Significantly, genocidal acts committed by the Nazis against homosexuals ${ }^{10}$ were not recognized as such, because, as genocide scholar Jack Porter notes, "under the Nuremberg Laws in which genocide was defined after the war, the killing of homosexuals was not considered a crime against humanity or a war crime." ${ }^{11}$ Porter also notes that the anti-gay bias of major genocide scholars themselves has led them, at best, to dismiss considering whether gays and lesbians were victims of the Nazi genocide, and, at worst, to categorize them as "criminals, perverts, and deviants."12 
Today, five nations (Iran, Mauritania, Saudia Arabia, Sudan, Yemen, and parts of Nigeria and Somalia) punish homosexual acts with death, and another eighty countries criminalize homosexuality. ${ }^{13}$

Although the original UNCG classification of genocide did not include social (or political) groups, the recent International Criminal Tribunal for Rwanda established such a precedent by defining possible victims as a group sharing a common culture. ${ }^{14}$ Further, Mohammed Abed identifies the features that make social groups vulnerable to genocide, and articulates a compelling case for including gays and lesbians in genocide research. ${ }^{15}$ The United Nations has also begun to formally recognize human rights violations based on sexual orientation and gender identity. In 2008, sixtysix countries (including the United States) signed the United Nations' statement "Human Rights, Sexual Orientation, and Gender Identity" that condemns human rights violations based on sexual orientation and gender identity. Citing this UN statement, on 4 June 2009, the Organization of American States' General Assembly adopted Resolution 2504, which went much further than condemning such acts. ${ }^{16}$ Noting "with concern acts of violence and related human rights violations perpetrated against individuals because of their sexual orientation and gender identity," the OAS resolution urged states to ensure that such acts "are investigated and their perpetrators brought to justice." Finally, the Resolution called for the Committee on Juridical and Political Affairs to include this issue on its next agenda and for the Permanent Council to report to the General Assembly at its next session on its implementation.

Given these developments, an analysis of ex-gay movement ideology, discourse, and political strategy will lend clarity to our research questions: To what extent does ex-gay ideology constitute part of the genocidal continuum against LGBT peoples? To what extent does the ex-gay movement advocate genocide based on the 1948 UNCG definition? Analyzing movement texts, we use James Waller's ${ }^{17}$ social psychological theory to assess the extent to which this movement promotes public policies that constitute genocide and the social death of LGBT peoples.

\section{The Ex-Gay Movement: Origin and Global Emergence}

Social scientists have long established that social movements are powerful agents of social change. During the past forty years, conservative Christian political organizations in the United States have mobilized to counter social changes advanced by feminist and gay and lesbian liberation movements. During this same period, the ex-gay movement, a lesser-known phenomenon, has grown steadily from a handful of evangelical Christian ministries in the early 1970s into a global movement in the twenty-first century, seeking to advance an ambitious public policy agenda. ${ }^{18}$

The ex-gay movement is predominantly an evangelical Christian Right social movement which aims to purge society of homosexuality and transgenderism. It was formed in the early 1970s to counter the American Psychiatric Association's declassification of homosexuality as a mental disorder in 1973. The movement promotes the belief that same-sex attraction (SSA) is a developmental gender identity disorder; that homosexual identity and behavior are inherently sinful and destructive to society; and that "people with SSA" can be re-oriented to heterosexuality through religious and/or psychological interventions. In response, prominent medical and mental health associations in the United States have issued statements opposing "reparative" and "conversion" therapies, and have discouraged professionals from attempts to change sexual orientation. ${ }^{19}$ Today, the movement has grown into an international network of religious, scientific, and political organizations using the 
existence of "ex-gays" to claim that homosexuals can change. This notion is fundamental to their political argument that unlike legal protections based on immutable traits such as race or sex those based on sexual orientation are not legitimate. ${ }^{20}$

As we will show, in the public policy arena, and pertinent to the UNCG articles II(b)-(e), ex-gay organizations and advocates have sought to legitimize potentially harmful therapies; uphold the criminalization of private homosexual sexual relations between consenting adults; prevent legal family recognition of same-sex couples; and advocate legislation that would prevent gays and lesbians from adopting children, serving as foster parents, or having access to medical technologies that would enable them to become parents. In addition, they oppose including sexual orientation or gender identity in hate crime statutes and anti-discrimination policies.

For decades, the Christian Right has amassed recruits and resources in the United States through anti-gay politics. ${ }^{21}$ In the twenty-first century, it is using gender and sexuality as prime vehicles to consolidate power on a global scale. The ex-gay movement is a vital component of its domestic public policy strategy and its evangelical strategy abroad. The movement is rapidly globalizing, and has been imported to some of the most dangerous environments in the world for sexual and gender minorities. ${ }^{22}$ Recent scholarship illustrates that American Christianity is increasingly influencing policies and programs worldwide through the growth of support for missionaries and churches in other countries and in short-term volunteer efforts abroad. ${ }^{23}$ Few are noticing this movement's global proliferation, their use of "hate group" propaganda, their misuse of science, or the movement's social impact.

\section{Theoretical Framework}

James Waller ${ }^{24}$ synthesizes a large body of social and psychological scholarship, organized as a general model, to explain how ordinary people commit extraordinary acts of brutality. His model presents a wealth of empirical support for the proposition that perpetrators of cruelty are not exceptional, and that committing acts of genocide, like other atrocities, does not require evil personalities. Rather, the evidence demonstrates that a host of social forces and environmental factors influence such behavior. In Waller's scheme, there are three major social processes that explain how individuals become capable of perpetrating brutality toward others: the cultural construction of a worldview, the psychological construction of the other, and the social construction of cruelty, each of which are further subdivided into additional social processes.

The "cultural construction of worldview" refers to the socially constructed framework that shapes individual perceptions of reality and subsequently influences behavior. The three components of worldview are: (1) collectivistic values based on a group identity (these include obedience, conformity, tradition, and order); (2) an "authority orientation" that promotes rigid, hierarchical relations of power; and (3) social dominance, which establishes the group's belief in its own supremacy and its desired control over other groups.

In the second part of the model, "psychological construction of the other," Waller outlines the social death processes that explain how perpetrators of brutality become capable of harming their victims, while distancing themselves from moral culpability for their actions. "It is the moral exclusions ... that help us understand how victims move from person to nonperson and how perpetrators move from ... coming to believe that it is not only right to harm their victims, but it would be wrong not to do so." 25 Three social processes are involved: (1) us-them thinking, (2) moral disengagement, and (3) blaming the victim. Us-them thinking explains how perpetrators 
engage in social distancing from their target. Here perpetrators use ethnocentrism and xenophobia to redefine victims from persons to nonpersons. Moral disengagement occurs when perpetrators distance themselves from the moral implications of their actions by behavioral justification, the dehumanization of the victims, and euphemistic labeling of their actions toward the target group. Blaming the victim involves attaching culpability to victims for their plight. Perpetrators avoid feelings of guilt since victims are presumed responsible for their own troubles.

The final component of Waller's model, "social construction of cruelty," explains how perpetrators are enveloped by a social context that encourages and rewards cruelty. There are three processes involved: (1) professional socialization, (2) ritual conduct, and (3) the binding factors of the group. Professional socialization refers to the process by which perpetrators assume social roles that encourage them to engage in outwardly small, escalating commitments which induce later obligations for further conformity. Ritual conduct aids in socializing perpetrators for their role and coping with their cruel behavior. The role begins to shape the individual and his/her behaviors toward others. Once the self merges with the role, perpetrators solidify their identities as group members. One's group identification enables an individual to repress his/her own conscience and diffuse individual responsibility. The final process explains how the desire for acceptance and group pressure to conform further binds the individual to group demands.

\section{Methods}

We use extensive content analysis of ex-gay movement organizational "texts," including the vast literature of printed, online, and audio materials created and promoted by ex-gay organizations. Overwhelmingly, these "texts" represent the views of movement entrepreneurs, and the official positions of four prominent ex-gay organizations are included in this analysis: Exodus International (hereafter referred to as EXODUS), the largest network of evangelical Christian ex-gay ministries, founded in 1976; its global counterpart, Exodus Global Alliance (hereafter referred to as EGA); the National Association of Research and Therapy of Homosexuality (hereafter referred to as NARTH), founded in 1992, which views homosexuality as a developmental disorder; and Focus on the Family (hereafter referred to as FOCUS), co-founded in 1977 by James Dobson, which seeks to impact public policy from an evangelical Christian perspective and sponsored (until 2009) the ex-gay "Love Won Out" (LWO) conferences.

\section{The Ex-Gay Worldview: Collectivist Values, Authority Orientation, and Social Dominance}

Our analysis will illustrate how ex-gay movement entrepreneurs and organizations fulfill the criteria of Waller's model. In the sections that follow, we explain how the movement constructs its collectivist worldview, psychologically constructs homosexuality and homosexuals, and encourages and rewards adherents to perpetrate cruelty against gays and lesbians.

The worldview promoted by the ex-gay movement is based primarily on one's identity as a Christian and the oft-repeated "values" that ostensibly distinguish Christians from non-Christians. The movement defines "Christian" as mutually exclusive from "gay." Further, anyone who embraces a LGBT identity is considered "non-Christian," regardless of that person's own religious identity, and such nonChristians are accused of embracing entirely different values and worldviews. Randy 
Thomas, vice president of EXODUS, calls these two perspectives "warring worldviews." 26 From this perspective, Christians are defined by their belief in and obedience to the will of God, for which the Christian Bible is held to be the sole authority. This authority orientation requires believers to submit absolutely to what they believe to be the inerrant word of God, and to accept scriptural authority as supreme. Patricia Lawrence, former executive director of EGA, illustrates this point: "Listen, scripture is the authority of Christians, it is the way that God speaks to us, and we must stand firm next to the word of God, because if we don't, then why are we Christians, because we have nothing ... This tells us how to live."27 Alan Chambers, President of EXODUS, also establishes this view as supreme to any potentially competing authority:

[S]cience can never and should never trump the word of God ... [which] is the final authority on this issue. The Bible ... calls homosexuality ... a sinful condition ... our Christian worldview has to be separate from that of the world, from that of science ... God wants us to live lives that are submitted to Him. ${ }^{28}$

Waller explains that collectivist values define an in-group and an out-group, make extreme categorical judgments between groups, and police that boundary. Ex-gay leaders construct acute differences between Christians and gays, including holy/ unholy; healthy/diseased; victim/predator; obedient/disobedient; penitent/unrepentant; and saved/condemned. From this worldview, being a "Christian" is the only divinely sanctioned identity and being "gay" is a selfish, corrupt, and a contemptuous affront to the will of God.

Finally, the ex-gay worldview promotes Christian supremacy and social dominance. Believers proclaim theirs is the one true God, and their biblical mandate is to manifest God's Kingdom throughout the world, what they often refer to as the "Great Commission." Michael Brown, author of Revolution: The Call to Holy War, a speaker for EXODUS and FOCUS, wrote:

We often conceal ours [Christian views and aims], trying to convince worldly people that our views are not really extreme, that our faith is completely reasonable, that our aims are not radical at all. Nonsense! As Christians, we believe that everyone who rejects our message will be sentenced to eternal punishment by God. That's extreme! We believe that anyone who does not know the Lord, is a child of Satan. That's extreme! ... We believe it is our mission in life to reach the entire world with the gospel of Jesus, calling all people to believe in Him. That's extreme! And we believe that God's Word is the standard by which everyone will be judged, in which case, all who have not been born again are ungodly sinners. That's extreme! ${ }^{29}$

\section{Constructing Gays: Us-Them Thinking, Moral Disengagement, and Blaming the Victim}

In this section we apply the social psychological processes that explain how ex-gay movement leaders construct gays and lesbians as non-persons and thus become capable of harming them, while distancing themselves from moral culpability for their actions.

\section{Us-Them Thinking}

The ex-gay movement divides "us" and "them" into two basic groups: Christians and non-Christians, yet claims it is God who makes these distinctions and treats each accordingly. In addition, the movement claims, people choose sides; therefore, each 
individual is responsible for his or her eternal fate. Patricia Lawrence, former executive director of EGA, illustrated this when she declared, "There are two identities in this world. We are either children of Satan, or children of God." "30 Lawrence subsequently spelled out the consequences for those who choose to be "children of Satan": "... let those homosexuals enjoy their life here on Earth, because they are going to spend an eternity in Hell." 31 Movement leaders see themselves as "God's people" doing His will, which enables them to justify their conduct as righteous.

The primary way that ex-gay leaders socially distance themselves from their victims, as well as their own actions, is by denying that there are homosexual people, and thus denying the reality of a victim at all. They do this by defining homosexuality as sin, sickness, or a social threat. Homosexuality is variously described as behaviors, attractions, identities, or more insidiously, as a sinful "lifestyle," a mental illness, or a menacing social "agenda," thus denying the personhood, indeed the existence-and the victimization of gay and lesbian people. Constructing homosexuality as a disorder, Joseph Nicolosi, a NARTH co-founder, emphasizes:

There is no such thing as a homosexual. There is no such thing as a homosexual ... [A] father called me up a little while back. He said "Our 15 year old son just announced to us that he is homosexual and we are trying to find a psychologist that we can trust who can tell us is he homosexual or not." I said "He is not." They said "How do you know? You haven't seen him yet." I said "He is designed for a woman ... He is heterosexual but he may have a homosexual problem." 32

In constructing homosexuality as a sinful condition and offering redemption, the exgay movement appears to encourage Christians to be compassionate toward homosexuals. Julie Harren Hamilton, current NARTH president, describes this process at an EXODUS conference:

It puts it in a different light instead of just seeing it as awful and ugly sin ... [I]t takes the focus off of the sin and puts it onto the person who is hurting and lets you see them in a new light. Instead of just "sinner" you now see "hurting person who needs God's love." 33

In these ways, ex-gay leaders deny there are any victims of their actions. If homosexuality is a condition, "treating" people with same-sex attractions is reconstructed euphemistically as compassionate and humane, not dehumanizing. However, once homosexuality is redefined as something non-human, it can be called anything or acted upon without recrimination. And it is.

Moral Disengagement. Once homosexuality is redefined as an object-a behavior, a condition, or an "agenda," it is demonized and blamed for a variety of social evils. Alan Chambers, EXODUS president, along with others, repeats this catchphrase frequently at ex-gay conferences: "The opposite of homosexuality is not heterosexuality, it's holiness." 34 This is a euphemistic way to say homosexuality is evil. The Southern Poverty Law Center, which tracks "hate groups" in the United States, quoted Chambers thus: "We have to stand up against an evil agenda. It is an evil agenda and it will take anyone captive that is willing, or that is standing idly by." 35 Note the rhetorical differences for distinct audiences. Chambers employs euphemism at ex-gay conferences and more explicit demonizing language at political strategizing meetings.

For Waller, there are three practices that enable people who commit brutality to morally disengage from their victims, which function to "make their reprehensible conduct acceptable and to distance them from the moral implications of their 
actions." 36 These are moral justification, dehumanization, and euphemistic labeling of evil actions. The ex-gay movement justifies its condemnation of homosexuality as a directive from God, which for them is scripturally validated (tautology notwithstanding). By claiming to follow God's will rather than their own, they deny responsibility for their beliefs and actions. Additionally, the movement has developed a secular ideology that blames homosexuality for an assortment of social evils. Throughout the process of moral disengagement, movement leaders frequently rely on the propaganda of organizations designated as hate groups by the Southern Poverty Law Center to justify their secular claims.

Ex-gay proponents portray homosexuality and homosexuals as a contagious threat that spreads and unleashes all kinds of social ills in its wake. They repeatedly refer to homosexuality or its advocacy movement as a "threat to the family," a "threat to traditional values," a "threat to religious freedom," and a threat to human civilization itself. They also claim that homosexuals themselves are a threat. James Dobson, FOCUS co-founder, condemns homosexuals as the ultimate social threat: "Homosexuals are not monogamous. They want to destroy the institution of marriage. It will destroy marriage. It will destroy the Earth." ${ }^{37}$ To counter such a grave danger, exterminating homosexuality is not only morally justified, it is a societal imperative.

Ex-gay leaders attempt to justify their genocidal intentions by portraying their actions as morally and socially necessary against the enormous threat posed by homosexuality, the "homosexual agenda," and homosexuals themselves. In doing this, they both minimize and deny the systematic oppression and victimization of gays and lesbians and construct themselves as victims of a destructive and sinister "homosexual agenda." In addition to "denying a victim" by constructing homosexuality as behavior, they minimize and deny anti-gay persecution and oppression, allege that homosexuals are privileged, and portray them as violent aggressors.

Denial of the Victim: The Myth of Gay Affluence. One way to diminish sympathy toward a group and lessen public support for protecting members from discrimination is to minimize their victimization and portray them as privileged. This is precisely how ex-gay groups use the claims made by Anton Marco. The claim that gays seek "special rights" is a well-worn rhetorical tactic of the Christian Right. ${ }^{38}$ The exgay movement elevates this approach by promoting the belief that gays and lesbians are wealthier than the rest of society. Marco alleges that "[h]omosexuals have an average household income of $\$ 55,340$ versus $\$ 32,144$ for the general population and $\$ 12,166$ for disadvantaged African-American households." ${ }^{39}$ In 2008, EXODUS VicePresident Randy Thomas declared, "The gay identified community is the most prosperous, median salary wise, community in the country." ${ }^{40}$ Citing Marco, NARTH extensively treats this subject: "For decades homosexual activists have fostered the impression that gays are economically, educationally, and culturally disadvantaged. Yet recent marketing studies, done by gay-run marketing agencies ... roundly refute those claims." ${ }^{41}$ Economists disagree and refer to this rhetorical tactic as "The Myth of Gay Affluence." ${ }^{42}$ Herman $^{43}$ notes this discourse evokes a familiar strategy used to demonize other groups.

While the ex-gay movement morally disengages from their victims by disavowing anti-gay oppression (especially their own culpability), they simultaneously portray themselves as victims of those they subjugate. Scholars ${ }^{44}$ have documented a pervasive rhetoric of victimhood adopted by anti-gay Christian conservatives, who recast themselves as an oppressed minority. Stein notes that this enables them to feel rage and mobilize their members to act on their behalf against those they define as 
the enemy. Ex-gay leaders brand "militant" gays as "anti-Christian" aggressors, reversing the victim-victimizer role, a stock dehumanization tactic. ${ }^{45}$

\title{
Dehumanization and Demonization: How Victims Become Victimizers
}

By claiming to target homosexuality, and not people, as the object of annihilationand defining that as sin, illness, or a perilous political agenda-is one way ex-gay movement leaders dissociate themselves from the harm they inflict on people. Despite this, the movement does indeed dehumanize and demonize gays. Perhaps the most malicious form in which this manifests is the stereotype that gays are prone to sexual predation, and are likely to molest children. Waller notes that dehumanization often involves "using categories of negatively evaluated unhuman creatures (such as demons and monsters)."46 Michael Brown, a speaker at EXODUS and FOCUS ex-gay conferences, wrote about the "seductive" threat of homosexuality:

\begin{abstract}
Satan certainly has his strategy, and it is multifaceted, multipronged, and bent on multiplication: One Satan touched life quickly touches another! [The superscript leads to this:] ... [I]t has been noted that homosexuals cannot increase by reproduction but only by seduction. Thus many gays are not merely content with having the right to live the way they want to without "discrimination"; rather, they want to encourage others to join them in their lifestyle. ${ }^{47}$
\end{abstract}

James Dobson invokes the specter of the homosexual pedophile in his parenting book: "Moms and Dads, are you listening? This movement is the greatest threat to your children. It is a particular danger to your wide-eyed boys, who have no idea what demoralization is planned for them." 48 He cites the expertise of NARTH cofounder Joseph Nicolosi to substantiate claims about homosexuality and pedophilia. At a FOCUS 2007 LWO conference, Nicolosi told the audience:

Sexual abuse, man/boy sexual contact and homosexual outcome-one third of our clients were sexually abused by older boys or men. And in the personal histories of gay men we often see same-sex abuse. This is in the literature. And we know that those who abuse become abusers. Gay activists get very, very angry when we make these connections but the scientific evidence is there. In addition gay activists are more likely to lobby for lowering the age of sexual consent. ${ }^{49}$

Finally, EXODUS board member Don Schmierer claims in his book on the prevention of homosexuality: "Sexual abuse, including molestation and/or rape, is a key factor in homosexuality. We will return to this repeatedly because it is so significant."50 Prominent movement figures, including Schmierer and Nicolosi, in EXODUS, EGA, NARTH, and FOCUS frequently cite the discredited research of Paul Cameron to demonize gays. Cameron was expelled from the American Psychological Association in 1983 for refusing to cooperate with an ethics investigation of his work. He was rebuked by the American Sociological Association in 1985 and 1986 for consistently misrepresenting sociological research on homosexuality, and for substantiating his anti-gay political advocacy with his distortions. ${ }^{51}$ The Southern Poverty Law Center designates his organization, the Family Research Institute, as an anti-gay "hate group." Despite all this, Cameron's publications, and those who reference them, ${ }^{52}$ continue to be cited by ex-gay representatives to support genocidal practices in court decisions and public policy. ${ }^{53}$

\section{Gays Are Violent}

Another dehumanizing theme in the rhetoric and propaganda promoted by ex-gay organizations is that gays are violent. Paul Cameron's essays are a chief source 
for the claim that gays are more likely to sexually violate children. In addition, Cameron alleges that gays are more likely than heterosexuals to be mass murders, serial killers, and abusive domestic partners. ${ }^{54}$ Cameron is not the only anti-gay propagandist promoted and utilized by ex-gay organizations. In 2009, EXODUS was criticized because board member Don Schmierer was one of three American speakers to participate in an anti-gay conference in Kampala, Uganda. At the conference, the main organizer and anti-gay propagandist, US citizen Scott Lively, allegedly blamed the Rwandan genocide on gay men. ${ }^{55}$ Lively co-authored The Pink Swastika: Homosexuality and the Nazi Party, ${ }^{56}$ excerpts of which were linked to EXODUS' and NARTH's websites until 2009. The book's primary objective is to deny that homosexuals were "targeted for extinction by the Nazis" and to depict them instead as aggressors. ${ }^{57}$ From the preface:

The Pink Swastika is a response to the "gay political agenda" and its strategy of portraying homosexuals as victims of societal and Nazi persecution ... there was far more brutality, rape, torture and murder committed against innocent people by Nazi deviants and homosexuals than there ever was against homosexuals ... The Pink Swastika will show clearly how the world the Nazis attempted to create is a world not of the past, but of the possible future ... given its present course and left unchallenged, America could easily become the Nazi Germany of 50 years ago. ${ }^{58}$

The Southern Poverty Law Center regards Lively's organizations, Abiding Truth Ministries and Watchmen on the Walls, as anti-gay hate groups. ${ }^{59}$ (Another Watchmen co-founder, Ken Hutcherson, was a keynote speaker at EXODUS' 2007 conference and at a 2008 FOCUS conference.) The Uganda People News reported that Uganda's Minister of Ethics and Integrity James Nsaba Buturo told conference attendees that he would submit a bill to parliament because the penal code criminalizing homosexuality is too weak. The article noted: "Scott Lively says it is good for the government of Uganda to criminalize homosexuality but the government should subject ... criminals ... to a therapy rather than imprisoning them."60 Uganda's law allows for life imprisonment as a maximum sentence for homosexual sex, and a seven-year sentence for attempting to commit "unnatural offences." ${ }^{2}$ In 2007, Lively called homosexuality a "a very fast-growing social cancer" and urged Russia to "criminalize the public advocacy of homosexuality. ${ }^{62}$

Blaming the Victim. The ex-gay movement morally disengages from its victims by minimizing and denying anti-gay oppression, and by stereotyping, demonizing, dehumanizing, and blaming "people living in homosexuality." When movement entrepreneurs acknowledge that gays and lesbians confront adversity, they attribute such hardships to "the homosexual lifestyle"-that is, to the people themselves. Blaming the victim is key to promoting moral disengagement. According to Waller,

If victims are to blame for their fate, then there is no reason for the perpetrators to feel guilty. The moral foundation of much evil doing rests on the principle that because of their damaging behaviors, certain individuals or target groups forfeit their rights to humane treatment and can be harmed without guilt or remorse. ${ }^{63}$

If homosexuality is a sinful choice or a mental disorder, then anything that happens to those who choose this behavior or refuse the "change" that is offered by ex-gay organizations is their fault. The ex-gay movement uses this logic to blame gays for AIDS, along with mental health problems such as depression, suicide, and the hate violence targeting them, rather than anti-gay oppression. 
Spokespersons of the ex-gay movement acknowledge that the advent of AIDS was a boon to them. Former EXODUS President Sy Rogers called its influence "profound." 64 The movement capitalized on and continues to exploit AIDS as proof of the destructive nature of the "homosexual lifestyle." Portraying homosexuality as a "culture of death" is the same victim-blaming tactic that was so effectively used by the phrase "culture of poverty" to blame the poor for their own indigence. Ex-gay leaders cite the "research" of Paul Cameron to allege that homosexuals have drastically shortened life spans. Cameron proposed tattooing and quarantining "sexually active homosexuals" 65 and AIDS patients, ${ }^{66}$ and, at the 1985 Conservative Political Action Conference, political scientist Mark Pietrzyk quoted Cameron when he told the audience, "Unless we get medically lucky, in three or four years, one of the options discussed will be the extermination of homosexuals." 67 According to an interview with former Surgeon General C. Everett Koop, "Cameron was recommending the extermination option as early as 1983."68 Movement entrepreneurs, such as NARTH board member Christopher Rosik, ${ }^{69}$ blame the "homosexual lifestyle," not oppression, for higher rates of stress-related psychiatric disorders and substance abuse, despite evidence that links these directly to "minority stress."70 According to the APA,

the evidence clearly supports the position that the social stigma, prejudice, discrimination, and violence ... and the hostile and stressful social environment created thereby adversely affects the psychological, physical, social and economic well-being lesbian, gay, and bisexual individuals. ${ }^{71}$

Even hate-motivated violence has been denied or blamed on gays themselves. Anthony Falzarano, founder of Parents and Friends of Ex-Gays and Gays (an EXODUS member organization until 2009), implied that gay men are attacked for preying on heterosexual men. He blamed Matthew Shepard, the gay college student from Wyoming, for his own murder: “... that poor unfortunate boy in, where was it? South Dakota? That man was a predator to heterosexual men." 72 In 2009 the Matthew Shepard and James Byrd, Jr. Hate Crime Prevention Act became law, adding sexual orientation and gender identity to federal hate crime statutes. Ex-gay leaders vigorously opposed this bill, alleging that it would be used to "silence Christians" and destroy religious freedoms. ${ }^{73}$ In addition to blaming Shepard for his own death, some ex-gay advocates deny that sexual orientation bias played any role. At a LWO conference, Dick Carpenter attempted to reframe Shepard's murder as a drugrelated robbery:

Gay activists have been and continue to exploit the unfortunate death of this young man ... And we often hear that Matthew Shepard was killed because of his sexual orientation. Well some months ago a well-known news program revisited the story of Matthew Shepard and what they discovered was a different story ... that Matthew Shepard was not necessarily killed because of his sexual orientation but because of drugs and money. But that's not what we hear now. ${ }^{74}$

Portraying Shepard as a predator and/or drug user, and not a victim of an anti-gay hate crime, at best, fosters indifference and minimizes the reality of hate crimes based on sexual orientation; at worst, it reinforces horrific stereotypes of gays and suggests that Shepard got what he deserved.

\section{“God's Solution": The Social Construction of Cruelty}

In 2007, FOCUS board member Albert Mohler created a national controversy after stating, 
The scientific evidence is mounting that human sexual orientation may be fixed by genetic and biological factors. Th[is] discovery ... would not change the Bible's moral verdict on homosexual behavior. Rather than excusing homosexual behavior, such a genetic discovery could lead to pre-natal ways to eliminate homosexual orientation and Christians should support such a development ... we should unapologetically support the use of any appropriate means to avoid sexual temptation and the inevitable effects of $\sin ^{75}$

The final part of Waller's model, the social construction of cruelty, explains how perpetrators of genocide become enveloped by a context that encourages and rewards cruelty. We apply three processes: (1) professional socialization, (2) ritual conduct, and (3) binding factors of the group.

\section{The Ex-Gay Role: Christian Missionaries on the Battlefield}

The ex-gay movement socializes and trains disciples to internalize its religious, psychological, and political ideology of homosexuality, transforming them into Christian missionaries and warriors whose role is to convert non-believers, obliterate homosexuality, and usher in the Kingdom of God as they understand it. EGA board member Darryl Foster instructed: "All of us are ministers. You don't have to go to ... seminary." 76 Leaders train disciples to effectively evangelize, strategically using a rhetoric of love, which also helps them distance themselves from the perception that they are hateful. ${ }^{77}$ Ex-gay conferences and publications also seek to equip followers to engage in the culture war. War rhetoric is a prominent feature of movement discourse, which is frequently cited as biblical. ${ }^{78}$ Leaders are careful to disavow violence, although Michael Brown writes about the need for "holy hatred" as a motivating force. ${ }^{79}$ In socializing believers to fulfill their roles as missionary-warriors, leaders emphasize biblical authority and obedience to God's will, which mandates imparting their beliefs. Brown encouraged his audience to imagine themselves as revolutionaries, as "God's solution" to the problem of homosexuality. He plainly asserted that the "cost" of following Jesus demands a readiness to die fighting for the cause and the risk of literal death:

The church needs to stand up ... If we don't become salt and light what happens next? We need to develop a revolutionary mentality ... This is how a revolutionary thinks ... Life as it is is not worth living but the cause is worth dying for ... This is not just an option. A revolutionary realizes that he is part of something bigger than himself. Revolutions don't happen ... at a tea party ... [they] come when people get to a breaking point, when they say "It's too late." "It's too far gone." "Life as it is is not worth living and I'd rather die fighting for what I believe in." 80

To bind followers to the demands of the group, leaders emphasize one's obligation to follow God's will, rather than their own, which absolves them of responsibility or guilt for their actions. Darryl Foster emphasizes absolute obedience, telling his audience: "We didn't write the Bible, but we are required to follow it." 81 To induce compliance, leaders appeal to the fear and/or self interest of believers by using threats of hell and promises of heaven, and other forms of social power. ${ }^{82}$ In addition, leaders make emotional appeals to compassion, ritually reminding disciples that not only their own, but the eternal destiny of others is at stake in carrying out God's will. ${ }^{83}$ Mobilizing believers is amplified by claims of the urgency of the situation, as Brown displays, and as Foster implores, claiming that Jesus will soon return: "This is the message we need to carry to the whole wide world ... [these are] perilous times... these are the last days." 84 Since 1973, the ex-gay movement has developed a mas- 
sive corporate infrastructure of religious, scientific, and political organizations in the United States and internationally. In addition to a global network of ex-gay ministries, the movement collaborates with most major Christian Right organizations, coordinates a network of churches and mental health counselors, manages an industry of ex-gay conferences and bookstores, and directs a variety of multimedia outlets to evangelize the ex-gay message and to advance genocidal policies at home and abroad.

\section{Genocidal Intentions}

We argue that the ex-gay movement organizations analyzed in this study advocate a genocidal ideology and public policy agenda targeting LGBT peoples on a global scale. Article II of the UNCG delineates several forms of conduct that constitute genocide. The ex-gay movement is actively pursuing public policies that would, if implemented, constitute state-sponsored genocidal practices in the United States and globally. The organizations analyzed in this study undeniably intend to purge society of homosexuality (whether by "prevention" or "treatment") and are actively working to destroy LGBT cultures worldwide. In 1990, Poland's president Lech Walesa promised in a televised speech that he would "eliminate from the country "moral undesirables' including homosexuals." ${ }^{85}$ In 2004, ex-gay psychotherapist Richard Cohen (expelled in 2003 from the American Counseling Association on several ethical violations) was invited to speak to Poland's parliament on "reparative" therapy, in response to a bill legalizing same-sex marriage. Cohen asked for $\$ 10$ million in funding to eradicate homosexuality in Poland and called for a bill to criminalize gay activism. ${ }^{86}$

Ex-gay organizations are actively pursuing policy positions that would, if implemented, constitute genocide under each of the UNCG articles under discussion here. Article II(b) recognizes genocide as acts that cause "serious bodily or mental harm to members of the group." Several prominent American medical and mental health associations have issued statements opposing therapies and treatments that are based on the assumption that homosexuality is a mental disorder, and discourage their members from attempting interventions aimed at changing sexual orientation, which they consider unethical and potentially harmful. ${ }^{87}$ In 2005, a Memphis-based EXODUS residential ministry, Love in Action, came under investigation by the Tennessee Department of Health for allegedly dispersing psychotropic medication and treating minors without a license in their "Refuge" program for youths between the ages of thirteen and eighteen. National news coverage revealed that some children were being forced by their parents to undergo "treatment" at Love in Action. Both FOCUS and NARTH encourage parents to subject their children to "treatment" regardless of the consent of their children. ${ }^{88}$ In 1997 the American Psychological Association issued a statement opposing attempts to change sexual orientation on several grounds, stating that "... children and youth often lack adequate legal protection from coercive treatment." 89 In 2009, an APA task force published the most comprehensive analysis of attempts to change sexual orientation to date. Regarding children and adolescents, the report concluded that such attempts "can pose harm through increasing sexual stigma and providing inaccurate information. We further concluded that ... involuntary or coercive residential or inpatient programs ... may pose serious risk of harm." 90 Forced therapy is also a concern where ex-gay organizations operate outside of the United States, as illustrated by the 2009 Uganda conference featuring hate group propagandist Scott Lively and EXODUS board member Don Schmierer. Although EXODUS claims to not condone forced treatment, 
Schmierer allegedly never voiced opposition during the conference to "treating" homosexual prisoners or criminalizing homosexuality. ${ }^{91}$ Schmierer's book, An Ounce of Prevention: Preventing the Homosexual Condition in Today's Youth, flaunts this quote from gay activist Frank Kameny among the book's endorsements: "We view your encouragement of prevention as tantamount to genocide ..."92

Article II(c) of the UNCG defines genocide as "deliberately inflicting on the group conditions of life calculated to bring about its physical destruction in whole or in part." In addition to the explicit intention to eradicate homosexuality via treatment or prevention, several of the ex-gay organizations analyzed in this study advocated criminalizing consensual, adult homosexual relations, and some movement leaders urge criminalizing gay advocacy. Sixteen states had such "sodomy" laws prior to the 2003 Lawrence v. Texas Supreme Court decision. FOCUS and the Alliance Defense Fund jointly submitted an amicus curiae brief defending the legality of these statutes. James Dobson (co-founder of ADF and FOCUS) called the Lawrence ruling an "outrageous decision." 93 Phil Burress, a 2005 EXODUS board member, wrote a letter in 2000 to the Republican National Convention Chair Jim Nicholson concerning the first speech ever given at the RNC by an openly gay man, Arizona legislator Jim Kolbe:

Mr. Kolbe as a self described homosexual means nothing except to say he engages in sodomy. Did you know that in Arizona, sodomy is against the law? Mr. Kolbe should be arrested when he returns to his home state for violating state law. Would you agree that all lawmakers should insist that all laws be enforced? ${ }^{94}$

Paul Cameron and colleagues proposed: "State sodomy laws should be written ... and enforced across the nation ... Legal acceptance/toleration of sodomy is a symptom of a decadent society." 95 EXODUS leaders also supported criminalizing homosexual conduct. ${ }^{96}$ EGA sponsored a conference in Barbados, where homosexual sex is illegal. The flyer read: "Some say decriminalize homosexuality ... we say let's offer solutions." 97

Articles II(d) and II(e) of the UNCG define genocide as "imposing measures intended to prevent births within the group" and "forcibly transferring children of the group to another group" respectively. Ex-gay organizations seek to deny reproductive technologies and adoption rights for homosexuals, and support policies and court decisions that have forcibly removed children from the custody of their parents solely based on their homosexuality. EXODUS' official policy states:

Exodus International believes that the biblical design for the family and the best environment for raising a biological or adoptive child is one in which the child's mother and father are married to one another and are present in the home. While legitimate and difficult circumstances often prevent this, the intentional deprivation of a mother or father through same-sex parenting and adoption, is not in the best interest of children ... [S] ocial policy and adoption law should be governed by a desire to ensure the health and well being of future generations. ${ }^{98}$

All the ex-gay organizations analyzed here are currently exhibiting the personal testimony of Canadian Dawn Stefanowicz, the daughter of a now-deceased gay man, who, citing Paul Cameron's distortions, claims that her tormented childhood substantiates that gay people are unfit to raise children. ${ }^{99}$ Stefanowicz, an accountant, appeals to her individual experiences and cites Cameron's statistics in testimony before legislatures in both Canada and the United States to deny parenting rights and reproductive technologies to gays and lesbians. ${ }^{100}$ Cameron and his colleagues 
recommended: "States should prohibit homosexuals, prostitutes, and drug addicts from adopting children, being foster-care parents, and having custody of children."101 Cameron's allegations, and those who cite him, such as Lynn Wardle, continue to be cited as credible research in amicus briefs, court decisions, and policy hearings in the United States. ${ }^{102}$ "Judges have cited Wardle's article to justify transferring child custody from lesbian to heterosexual parents." 103

Using the courts to deny parents custody of their own children is the primary means through which children are forcibly removed from one group and transferred to another. In 1995, the Virginia Supreme Court used the state's sodomy statute to justify forcibly transferring custody of Sharon Bottoms' two-year-old son to her mother. Ex-gay organizations today work with Christian Right legal firms, such as the Alliance Defense Fund and Liberty Counsel, which routinely submit court briefs and litigate to prevent or deny gay people from conceiving, adopting, fostering, and rearing children, even their own offspring. Since 2004, Liberty Counsel founder Mat Staver, dean of Liberty University's Law School, has represented Lisa Miller, an ex-gay woman who seeks to deny her co-parent's visitation rights. Miller claims her former partner's "lesbian lifestyle" results in a harmful environment for their daughter Isabella. Liberty Counsel and PFOX, an EXODUS ministry until 2009, cosponsor the "Protect Isabella Coalition" to provide legal support for this case. NARTH, which portrays itself as a secular mental health organization, featured Staver at its 2009 conference. In 2002, Alabama Supreme Court Justice Roy Moore wrote a post-divorce custody opinion, which denied guardianship to a lesbian mother:

To disfavor practicing homosexuals in custody matters is not invidious discrimination, nor is it legislating personal morality. [It] ... promotes the general welfare of the people of our State in accordance with our law, which is the duty of its public servants ... the protection of the family is a responsibility of the State. Custody disputes involve ... the State, within the limits of its sphere of authority, in a way that preserves the fundamental family structure. The State carries the power of the sword, that is, the power to prohibit conduct with physical penalties, such as confinement and even execution. It must use that power to prevent the subversion of children toward this lifestyle, to not encourage a criminal lifestyle. ${ }^{104}$

Moore is running for governor of Alabama in 2010. James Dobson is quoted on Moore's Web site: "Judge Moore is a man of courage and strong Christian character, and I have long admired him. Should he win the party primary, I will be pleased to endorse him for governor ..."105

\section{Conclusion}

If implemented, would the policies advocated by ex-gay movement organizations and representatives analyzed here constitute genocide? We have attempted to illustrate how the ideology, rhetoric, and practices of the ex-gay movement are congruent with Waller's explanatory model of how ordinary people commit extraordinary acts of brutality, and to reveal how this movement promotes public policies that, we argue, would constitute social death forms of genocide according to UNCG articles II(b)-(e). ${ }^{106}$ The ex-gay movement consciously desires the destruction of LGBT culture, and movement leaders have advocated upholding laws that would criminalize private consensual homosexual relations, allow potentially seriously harmful therapies, and deny parenthood to LGBT peoples. It promotes public policy, at home and abroad, designed to destroy the social vitality of LGBT peoples. According to Card, "Social vitality is destroyed when the social relations-organizations, practices, 
institutions - of the members of a group are irreparably damaged or demolished."107 It is purposeful and sustained action with full knowledge of the consequences of and expectation of extermination.

The genocidal agents in this case do not involve constitutional rulers of a state, but emissaries of a religious movement vested with a belief in divine sanction for their cause, and divine absolution for their brutality. The ex-gay worldview is constructed on what its entrepreneurs imagine to be a moral universe. Constructing homosexuality as a dangerous social threat further legitimates its destruction, and justifies the movement's foray into the public sphere. Its ideology leads to no other solution than annihilation. Denying that people are harmed by their actions is a form of ideological annihilation, a necessary short-term objective to establish credibility for their genocidal intentions and, ultimately, to summon state and medical intervention. By waging a culture war using hate propaganda and misusing scientific research to gain public legitimacy, the movement seeks to deploy state powers and the medical profession to perpetrate genocidal acts on its behalf. In the context of persistent stigmatization and increasing rates of hate crimes against sexual and gender minorities in the United States, escalating human rights violations against LGBT peoples worldwide, and the global proliferation of American evangelical Christianity, the ex-gay movement may potentially enable and facilitate the commission of genocide.

As an example of this movement's potential to influence nation-states, the situation in Uganda has worsened significantly since the March 2009 conference featuring Scott Lively, Caleb Brundidge, and EXODUS board member Don Schmierer. In October of 2009, a draft of the "Anti-Homosexuality Bill" 108 was introduced to Uganda's parliament. If passed, this law would mandate the death penalty for a range of different homosexual acts under the category "aggravated homosexuality," including repeated consensual homosexual sexual activity or engaging in homosexual activity if HIV positive. Further, it would mandate life imprisonment for a person who "purports to contract a marriage" to a person of the same sex. Finally, it allows for life imprisonment for a single consensual homosexual act, a maximum penalty of seven years in prison for the "promotion of homosexuality," and a maximum sentence of three years for anyone who does not report, within twenty-four hours, their knowledge of any offense committed under this act.

In response, government officials in the United States, France, and England have all issued public statements denouncing this bill, and have urged Uganda's parliament to withdraw its consideration. The Organization of American States and the sixty-six signatories of the United Nations' statement "Human Rights, Sexual Orientation, and Gender Identity" should use their individual and collective leverage to discourage support for this bill, which would send a message to the governments of other nations which might consider similar measures. In October of 2009, the United States offered $\$ 246$ million in new aid to Uganda. ${ }^{109}$ To evince their commitment to human rights as expressed by the 2008 UN statement and the 2009 OAS resolution, the Obama administration and Congress should tether this offer to the vote by Uganda's parliament on this proposed legislation.

Our research aims to contribute to the literature on predicting and preventing genocide, focusing on social death forms of genocide elaborated in the UNCG, articles II(b)-(e). We suggest that prioritizing research on genocide as mass murder may indeed enhance its moral opprobrium, but at an enormous human cost, including predicting and preventing mass murder. Further, given that international responses to genocide have been based primarily on political, and not moral, considerations, we 
advocate a fuller consideration of the UNCG definition. Revitalizing scholarship on social death will broadly enrich the field of genocide studies and enhance our collective efforts to forecast and avert genocide in all of its manifestations.

\section{Acknowledgments}

This research was funded by the Educational Leave and the Summer Research Grant Programs from the College of Arts and Letters at James Madison University. This paper was presented at the International and Interdisciplinary Conference on Human Rights, International Law, and Collective Violence in Elkins, WV, on 18 April 2009. The authors wish to thank Megan Kirk, Hannah Lacko, and Zach Wall for their research assistance on this project.

\section{Notes}

1. Frank Chalk and Kurt Jonassohn, The History and Sociology of Genocide (New Haven, CT: Yale University Press, 1990); Leo Kuper, The Prevention of Genocide (New Haven, CT: Yale University Press, 1981).

2. Convention on the Prevention and Punishment of the Crime of Genocide, 9 December 1948, 78 U.N.T.S. 277, http://www.unhchr.ch/html/menu3/b/p_genoci.htm (accessed 25 June 2009).

3. Michael Burleigh, Ethics and Extermination (Cambridge: Cambridge University Press, 1997); Robert Gellately and Ben Kiernen, The Specter of Genocide (Cambridge: Cambridge University Press, 2003); Barbara Harff, "A Theoretical Model of Genocides and Politicides," Journal of Ethno-Development 4 (1994): 25-30; Michael Ignatieff, "Intervention and State Failure," in The New Killing Fields, ed. Nicolaus Mills and Kira Brunner, 229-44 (New York: Basic Books, 2002); Adam Jones, Gendercide and Genocide (Nashville, TN: Vanderbilt University Press, 2004); Michael Mann, The Dark Side of Democracy (Cambridge: Cambridge University Press, 2004); Norman M. Naimark, Fires of Hatred (New Haven, CT: Harvard University Press, 2002); Samantha Power, A Problem from Hell (New York: Basic Books, 2002); Michael Walzer, "Arguing for Humanitarian Intervention," in The New Killing Fields, ed. Nicolaus Mills and Kira Brunner, 19-35 (New York: Basic Books, 2002).

4. Roy F. Baumeister, Evil (New York: W.H. Freeman, 1999); Claudia Card, "Genocide and Social Death," Hypatia 18 (2003): 63-79; Frank Chalk, "Definitions of Genocide and Their Implications for Prediction and Prevention," Holocaust and Genocide Studies 4 (1989): 149-60; Israel W. Charny, "Definitions of Genocide," in Encyclopedia of Genocide, ed. Israel W. Charny, 11-15 (Santa Barbara, CA: ABC-CLIO Press, 1999); Alexander Laban Hinton, Annihilating Difference (Berkeley: University of California Press, 2002); Nancy Scheper-Hughes, Death without Weeping (Berkeley: University of California Press, 1993); Ervin Staub, The Roots of Evil (New York: Cambridge University Press, 1989); James Waller, Becoming Evil (New York: Oxford University Press, 2007).

5. Orlando Patterson, Slavery and Social Death (Cambridge, MA: Harvard University Press, 1985).

6. Card, "Genocide and Social Death."

7. Ibid., 76.

8. Adam Jones, Genocide (New York: Routledge, 2006); Frank Chalk and Kurt Jonasson, The History and Sociology of Genocide (New Haven, CT: Yale University Press, 1990).

9. John Boswell, Christianity, Social Tolerance, and Homosexuality (Chicago: University of Chicago Press, 1980).

10. Geoffrey J. Giles, “The Most Unkindest Cut of All': Castration, Homosexuality, and Nazi Justice," Journal of Contemporary History 27 (1992): 41-61; Gunter Grau, Hidden Holocaust? Gay and Lesbian Persecution in Germany, 1933-45 (London: Cassell, 1995); 
Heinz Heger, The Men with the Pink Triangle (New York: Alyson, 1980); Jack Nusan Porter, The Genocidal Mind (Lanham, MD: University Press of America, 2006).

11. Porter, The Genocidal Mind, 116.

12. Ibid., 117.

13. Daniel Ottoson, State-Sponsored Homophobia (Brussels: International Gay, Lesbian, Bisexual, Trans, and Intersex Association, 2009).

14. Yusuf Aksar, "The 'Victimized Group' Concept in the Genocide Convention and the Development of International Humanitarian Law through the Practice of Ad Hoc Tribunals," Journal of Genocide Research 5 (2003): 211-24.

15. Mohammed Abed, "Clarifying the Concept of Genocide," Metaphilosophy 37 (2006): 30830 .

16. Organization of American States, Resolution 2435 (39th session, 2009), http://www.oas. org/DIL/AGRES_2435.doc (accessed 14 January 2010).

17. Waller, Becoming Evil.

18. Christine M. Robinson and Sue E. Spivey, "The Politics of Masculinity and the Ex-Gay Movement," Gender and Society 21 (2007): 650-75.

19. For a review, see the American Psychological Association Statement of 10 August 2006, http://www.apa.org/pi/lgbc/policy/0806exgay.pdf (accessed 16 August 2009).

20. Didi Herman, “(Il)legitimate Minorities,” Journal of Law and Society 23 (1996): 346-63.

21. Didi Herman, The Antigay Agenda (Chicago: University of Chicago Press, 1997); Janice M. Irvine, "Anti-Gay Politics On-Line," Sexuality Research and Social Policy 2 (2005): $3-21$.

22. A listing of ex-gay ministries in every country can be found at http://www.exodusglobalalliance.org.

23. Robert Wuthnow, Boundless Faith (Berkeley: University of California Press, 2009).

24. Waller, Becoming Evil.

25. Ibid., 203.

26. Randy Thomas, "Warring Worldviews and Our Redemptive Response" (Presentation at Exodus Freedom Conference, Irvine, CA, June 2007).

27. Patricia Lawrence, "Session C" (Presentation at Exodus Global Alliance Conference, Toronto, ON, May 2005).

28. Alan Chambers, "Practical Tips for Reaching Out" (Presentation at Love Won Out Conference, Phoenix, AZ, February 2007).

29. Michael Brown, Revolution (Ventura, CA: Regal Books, 2000), 171-73.

30. Lawrence, "Session C."

31. Patricia Lawrence, "Responding with Truth and Grace" (Presentation at Exodus Global Alliance Conference, Quebec, QC, November 2006).

32. Joseph Nicolosi, "The Condition of Male Homosexuality" (Presentation at Love Won Out Conference, Phoenix, AZ, February 2007).

33. Julie Harren, "To Educate the Public on the Issue of Homosexuality" (Presentation at Exodus Freedom Conference, Ridgecrest, NC, July 2005).

34. Chambers, "Practical Tips for Reaching Out."

35. Casey Sanchez, "Straight Like Me," Intelligence Report [Southern Poverty Law Center] 128 (2007), http://www.splcenter.org/intel/intelreport/article.jsp?pid=1469 (accessed 30 November 2008).

36. Waller, Becoming Evil, 202.

37. Carmel Perez Snyder, "Marriage, Family Advocate in State to Support Coburn," The Daily Oklahoman, 23 October 2004, 10A.

38. Herman, The Antigay Agenda.

39. Bob Moser, "Holy War," Intelligence Report [Southern Poverty Law Center] 117 (2005): 9-19.

40. Randy Thomas, http://randythomas.org/2007/03/30/la-shawn-questions-and-calls/ (accessed 20 June 2008). 
41. Anton Marco, "Gay Marriage" (NARTH, 2008), http://www.narth.com/docs/marco.html (accessed 10 July 2009).

42. M.V. Lee Badgett and Jefferson Frank, eds., Sexual Orientation Discrimination (London: Routledge, 2007).

43. Herman, The Antigay Agenda.

44. Arlene Stein, Shameless (New York: New York University Press, 2006); Susan Johnston, "On the Fire Brigade," Critical Sociology 20 (1994): 3-19.

45. Ruth Wodak, "Das Ausland and Anti-Semitic Discourse," in The Language and Politics of Exclusion, ed. Stephen Harold Riggins, 65-87 (Thousand Oaks, CA: Sage, 1997).

46. Waller, Becoming Evil, 206.

47. Brown, Revolution, 275, 335.

48. James Dobson, Bringing Up Boys (Wheaton, IL: Tyndale House, 2001), 127.

49. Nicolosi, "The Condition of Male Homosexuality."

50. Don Schmierer, An Ounce of Prevention: Preventing the Homosexual Condition in Today's Youth (Columbia, TN: Promise Publishing, 2002), 41.

51. Gregory M. Herek, "Bad Science in the Service of Stigma," Stigma and Sexual Orientation, ed. G.M. Herek, 223-55 (Thousand Oaks, CA: Sage, 1998).

52. Lynn D. Wardle, “The Potential Impact of Homosexual Parenting on Children," University of Illinois Law Review 3 (1997): 833-919.

53. Judith Stacey and Timothy J. Biblarz, "(How) Does the Sexual Orientation of Parents Matter?" American Sociological Review 66 (2001): 159-83, 161.

54. Paul Cameron, "Violence and Homosexuality" (Brochure) (Colorado Springs, CO: Family Research Institute, 1999); Paul Cameron, "Gay Domestic Violence Finally Measured," Family Research Institute Reports 16 (2001): 1-2; Paul Cameron, "The Violent Lives of Homosexual Couples," Family Research Institute Reports 18 (2003): 1, 5; Paul Cameron, "Domestic Violence among Homosexual Partners," Psychological Reports 93 (2003): 410-16.

55. Jim Burroway, "Uganda Anti-Gay Conference, Day Three," Box Turtle Bulletin, 8 March 2009, http://www.boxturtlebulletin.com/2009/03/08/9541 (accessed 8 March 2009).

56. Scott Lively and Kevin Abrams, The Pink Swastika (Keizer, OR: Founders Publishing, 1995).

57. Ibid., 63; Brown, Revolution, 39, alleges that the gay movement will be "violently aggressive."

58. Ibid., iv.

59. Intelligence Report [Southern Poverty Law Center] 128 (Winter 2007).

60. "New Bill on Homosexuality to Be Presented to Parliament," Uganda People News, 6 March 2009, http://www.ugpulse.com/articles/daily/news.asp?about=New bill on homosexuality to be presented to parliament (accessed 26 June 2009).

61. Ottoson, State-Sponsored Homophobia.

62. Scott Lively, "Letter to the Russian People" (Citrus Heights, CA: Abiding Truth Ministries, 2007), http://www.defendthefamily.com/pfrc/archives.php?id=5225300 (accessed 17 June 2009).

63. Waller, Becoming Evil, 218.

64. One Nation under God [DVD], dir. Francine Rzeznik and Todoro Maniaci (83 min., Frameline, 1993).

65. David A. Noebel, Wayne C. Lutton, and Paul Cameron, Special Report: AIDS Acquired Immune Deficiency Syndrome (Manitou Springs, CO: Summit Ministries, 1986).

66. Mark E. Pietrzyk, "Queer Science," The New Republic, 3 October 1994, 10-12.

67. Mark E. Pietrzyk, "The Man Behind the Myths: A Report on the Chief Anti-Gay Researcher of the Theocratic Right" News-Telegraph, 10 March 1995, archived by the Queer Resources Directory at http://www.qrd.org/qrd/religion/anti/cameron/log.cabin (accessed 10 June 2008).

68. Mark E. Pietrzyk. “The Ex-Files” (30 November 1999), http://www.indegayforum.org/ news/show/26866.html (accessed 13 June 2009). 
69. Christopher H. Rosik, "Conversion Therapy Revisited," Journal of Pastoral Care 55 (2001): 47-67.

70. American Psychological Association Council of Representatives, "Resolution on Sexual Orientation and Marriage," July 2004, http://www.apa.org/releases (accessed 15 August 2009).

71. Ibid.

72. People for the American Way, "Special Eye-Witness Report from the 3rd Annual PFOX Conference" (Washington, DC: People for the American Way Foundation, 9 April 1999).

73. Alan Chambers, Mike Haley, John Smid, and Randy Thomas, "Practical Tips for Reaching Out: Q\&A" (Presentation at Love Won Out Conference, Phoenix, AZ, February 2007).

74. Dick Carpenter, "Why Is What They're Teaching So Dangerous?" (Presentation at Love Won Out Conference, Phoenix, AZ, February 2007).

75. Julie Harren, "Educating the Church about Homosexuality" (Presentation at Exodus Freedom Conference, Irvine, CA, June 2007); Surina Khan, Calculated Compassion, (Washington, DC: Political Research Associates, 1998).

76. Darryl L. Foster, "Speak Up! Part II" (Presentation at Campus Crusade for Christ Impact Conference, Atlanta, GA, December 2008).

77. Brown, Revolution; Andy Comiskey, "The Grace to Persevere" (Presentation at Exodus Freedom Conference, Ridgecrest, NC, July 2008).

78. Brown, Revolution.

79. Michael Brown, "Developing a Revolutionary Mentality" (Presentation at Exodus Freedom Conference, Irvine, CA, June 2007).

80. Foster, "Speak Up! Part II."

81. Darryl L. Foster, "Life after the Lifestyle" (Presentation at the Exodus Global Alliance Conference, Toronto, ON, May 2005).

82. Lawrence, "Truth and Grace."

83. Ibid.

84. Foster, "Speak Up! Part II."

85. "International News: Eastern Europe Update," Ms. Magazine, January/February 1991, 13.

86. Tomek Kitlinski and Pawel Leszkowicz, "God and Gay Rights in Poland," The Gay and Lesbian Review Worldwide 12 (2005): 26-28.

87. See the American Psychological Association Task Force Report, Appropriate Therapeutic Responses to Sexual Orientation (Washington, DC: APA, 2009).

88. Jason Cianciotto and Sean Cahill, Youth in the Crosshairs: The Third Wave of Ex-Gay Activism, (Washington, DC: National Gay and Lesbian Task Force, 2006).

89. American Psychological Association Council of Representatives, "Resolution on the Appropriate Therapeutic Responses to Sexual Orientation" (Washington, DC: APA, 1997).

90. APA Task Force, Appropriate Therapeutic Responses to Sexual Orientation, 79.

91. Jim Burroway, "Videos Surface of Ugandan Activists Stirring Anti-Gay Fervor," Box Turtle Bulletin, 28 March 2009, http://www.boxturtlebulletin.com/2009/03/28/10171 (accessed 28 March 2009).

92. Schmierer, An Ounce of Prevention, i.

93. James Dobson, "In Defending Marriage-Take the Offensive!" Focus on the Family Newsletter (April 2004), http://www2.focusonthefamily.com/docstudy/newsletters/ A000000334.cfm (accessed 21 January 2010).

94. Phil Burress, "Arrest Mr. Kolbe," American Family Association Action Alert, 28 July 2000, archived by the American Civil Liberties Union at http://www.aclu.org/lgbt-rights_hivaids/calls-arrest-openly-gay-gop-convention-speaker-reveal-danger-sodomy-laws-nation (accessed 21 January 2010).

95. Noebel et al., Special Report: AIDS, 52. 
96. Randy Thomas, "Supreme Court Strikes Down Sodomy Laws," Exodus International (2003), http://www.exodus.to/content/view/494/37/ (accessed 11 August 2009).

97. "News from Around the World: Barbados," Exodus World News 1 (2006): 2, http:// www.exodusglobalalliance.org/files/WorldNews2006-01webversion_74.pdf (accessed 21 January 2010).

98. "Exodus International Policy Statement," Exodus International (2009), http://www. exodus.to/content/view/34/62/ (accessed 5 July 2009).

99. Dawn Stefanowicz, "Out From Under," NARTH Conference Report (Irving, TX, October 2007); Dawn Stefanowicz, "A Child's Experience," Exodus Global Alliance, http:// www.exodusglobalalliance.org/achildsexperiencep597.php (accessed 23 July 2009); Dawn Stefanowicz, Out from Under (Enumclaw, WA: Annotation Press, 2007); Dawn Stefanowicz, "What About the Children?" Focus on the Family Today's Family News, http://www.focusonthefamily.ca/tfn/protectmarriage 2006/articles/WhatAboutTheChildren. html (accessed 23 July 2009).

100. Stefanowicz, Out from Under.

101. Noebel et al., Special Report: AIDS, 66.

102. David Holthouse, "The Fabulist," Intelligence Report [Southern Poverty Law Center] 117 (2005); Stacey and Biblarz, "(How) Does the Sexual Orientation of Parents Matter?"

103. Stacey and Biblarz, "(How) Does the Sexual Orientation of Parents Matter?" 161.

104. Leon D. Keith, "Lesbian Mother in Alabama Custody Case Mulls Appeal," Associated Press, 28 March 2002.

105. “Judge Moore for Governor" (Judge Roy Moore for Governor 2010 Committee, 2009), http://www.moore2010.com/main (accessed 5 July 2009).

106. We invite scholars from all fields, especially experts in international law, to evaluate our assessment and to suggest policy approaches to redress these grievances.

107. Card, "Genocide and Social Death," 69.

108. See Bill No. 18: Anti-Homosexuality Bill 2009 (Uganda, 25 September 2009), archived at Box Turtle Bulletin, http:/www.boxturtlebulletin.com/btb/wp-content/uploads/2009/10/ Bill-No-18-Anti-Homosexuality-Bill-2009.pdf (accessed 22 November 2009).

109. “U.S. gives Uganda \$246 Million in New Aid," Thomson Reuters, 27 October 2009. 